\title{
Abdominal mass causing acute kidney injury as a manifestation of acute myeloid leukaemia
}

\author{
Helena Moreira, ${ }^{1}$ Luís Flores, $^{01}$ Inês Brito, ${ }^{2}$ Catarina Pedrosa ${ }^{3}$
}

${ }^{1}$ Internal Medicine Department, Centro Hospitalar Universitário de São João, Porto, Portugal ${ }^{2}$ Haematology Department, Centro Hospitalar Universitário de São João, Porto, Portugal ${ }^{3}$ Department of Pathology, Centro Hospitalar Universitário de São João, Porto, Portugal

\section{Correspondence to \\ Dr Luís Flores, \\ luisqfs@gmail.com}

Accepted 29 January 2019

\section{DESCRIPTION}

A 48-year-old previously healthy woman presented to the emergency department due to asymmetric oedema of the limbs, having been diagnosed with deep venous thrombosis of the left common femoral vein. Two weeks later, she went to her family physician by worsening oedema, asthenia and feeling of abdominal distension. CT of the abdomen and pelvis showed multiple adenopathies and an heterogeneous pelvic mass with $11 \times 11 \times 9.5 \mathrm{~cm}$ (figure 1), involving abdominal large vessels, colon, uterine appendages and peritoneum, causing bilateral ureterohydronephrosis. She was referred to the emergency department, where white blood cell count of $25300 / \mu \mathrm{L}$ with $53 \%$ blasts, oliguric acute renal injury and hyperkalaemia were identified. Although urinary diversion catheters were bilaterally placed, haemodialysis was needed. Bone marrow aspirate revealed $45 \%$ of immature cells compatible with acute myeloid leukaemia (AML). Cytogenetic analysis identified inversion 3 (inv3) and genetic analysis detected mutation of nucleophosmin 1 (NPM1), without fms-like tyrosine kinase 3 internal tandem duplication (FLT3-ITD).

A core needle biopsy of the abdominal mass was made. The histological examination revealed densely cellular neoplasm consisting of a diffuse proliferation of medium to large cells with scant cytoplasm. Occasional cells had more abundant granular cytoplasm. The nuclei were hyperchromatic with round to irregular contours and inconspicuous nucleoli (figure 2A). The cells showed diffuse immunoreactivity for myeloperoxidase (figure 2B), lysozyme and c-Kit (figure 2C). The morphologic and immunophenotypic findings were consistent with the diagnosis of myeloid sarcoma.

Induction chemotherapy according to EORTC-GIMENA AML12 protocol was started, with adjusted doses due to kidney failure. After one cycle of induction therapy, there were no circulating blasts, less than $5 \%$ of immature cells in the bone marrow and a small reduction of the size of the granulocytic sarcoma. Radiotherapy, directed to the abdominal mass, was initiated, but it had to be stopped later because of ineffectiveness and adverse effects. Our patient had grade 2 radiation enteritis, grade 4 oral mucositis, multiple infectious intercurrences and at discharge her Eastern Cooperative Oncology Group (ECOG) performance status (PS) was 3. Taking this into account, it was decided to start 5 -azacytidine to maintain response, but she relapsed, with reappearance of circulating blasts, after six cycles. By this time, she had an ECOG PS of 0 , so therapy with fludarabine, cytarabine, idarubicin (FLA-IDA) was immediately started as second induction cycle.

Myeloid sarcoma is a rare tumour consisting of myeloid blasts occurring at extramedullary anatomic sites, which can be the presentation of any subtype of AML. Presenting signs or

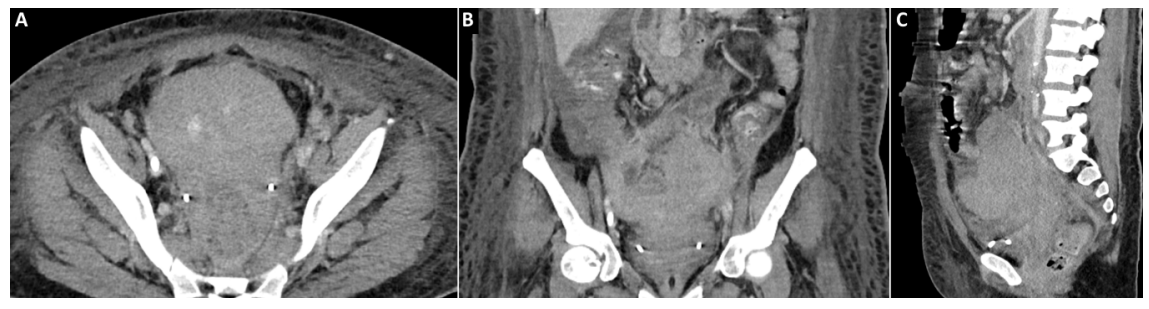

Figure 1 Heterogeneous pelvic mass on axial (A), coronal (B) and sagittal (C) plans of abdominal CT scan.

Check for updates

C) BMJ Publishing Group Limited 2019. No commercial re-use. See rights and permissions. Published by BMJ.

To cite: Moreira $H$, Flores $L$, Brito I, et al. BMJ Case Rep 2019;12:e228918. doi:10.1136/bcr-2018228918

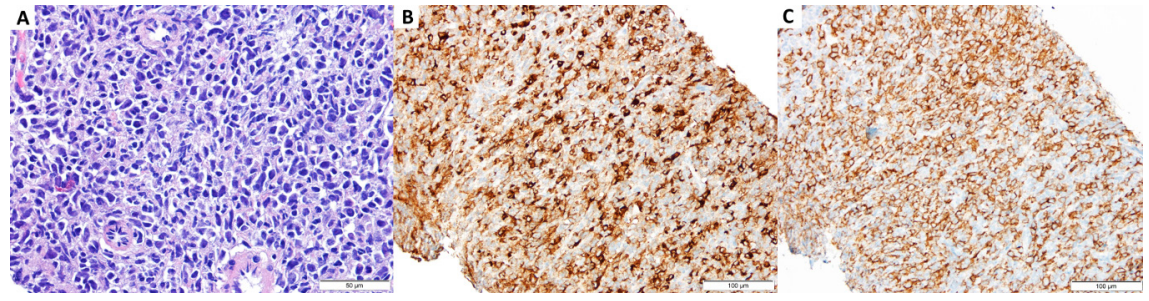

Figure 2 Histology (H\&E) showing a diffuse densely cellular proliferation of medium to large cells with scant cytoplasm and occasional cytoplasmic granules (A) and immunohistochemistry showing myeloperoxidase (B) and c-Kit expression (C). 
symptoms are mainly due to the mass effect of the tumour and dysfunction of the organ that is affected. The mainstay treatment of myeloid sarcoma is systemic chemotherapy, according to the subtype of AML. Surgery or radiotherapy may be necessary to correct organ disfunction or obstruction. ${ }^{1-3}$

\section{Learning points}

Myeloid sarcoma should be suspected when a mass is discovered in a patient with acute myeloid leukaemia.

- Myeloid sarcoma symptoms are mainly due to the mass effect of the tumour.

Acknowledgements Fernando Friões, M.D., Ph.D.; Fernanda Trigo, M.D.; Elsa Fonseca, M.D., Ph.D.
Contributors HM had theidea. HM, LF, IB and CP wrote the draft, reviewed and approved the finalversion. HM and LF contacted the patient. LF and CP edited the images.

Funding The authors have not declared a specific grant for this research from any funding agency in the public, commercial or not-for-profit sectors.

Competing interests None declared.

Patient consent for publication Obtained.

Provenance and peer review Not commissioned; externally peer reviewed.

\section{REFERENCES}

1 Almond LM, Charalampakis M, Ford SJ, et al. Myeloid sarcoma: Presentation, diagnosis, and treatment. Clin Lymphoma Myeloma Leuk 2017;17:263-7.

2 Bakst RL, Tallman MS, Douer D, et al. How I treat extramedullary acute myeloid leukemia. Blood 2011;118:3785-93.

3 National Comprehensive Cancer Network. Acute Myeloid Leukemia (version 1.2019). https://www.nccn.org/professionals/physician_gls/pdf/aml.pdf (Accessed 2019 Jan 25).

Copyright 2019 BMJ Publishing Group. All rights reserved. For permission to reuse any of this content visit https://www.bmj.com/company/products-services/rights-and-licensing/permissions/

BMJ Case Report Fellows may re-use this article for personal use and teaching without any further permission.

Become a Fellow of BMJ Case Reports today and you can:

- Submit as many cases as you like

- Enjoy fast sympathetic peer review and rapid publication of accepted articles

- Access all the published articles

- Re-use any of the published material for personal use and teaching without further permission

For information on Institutional Fellowships contact consortiasales@bmjgroup.com

Visit casereports.bmj.com for more articles like this and to become a Fellow 